Article

\title{
Burn Severity Dominates Understory Plant Community Response to Fire in Xeric Jack Pine Forests
}

\author{
Bradley D. Pinno * and Ruth C. Errington \\ Natural Resources Canada, Canadian Forest Service, Northern Forestry Centre Edmonton, Edmonton, \\ AB T6H 3S5, Canada; ruth.errington@canada.ca \\ * Correspondence: brad.pinno@canada.ca; Tel.: +1-780-430-3829
}

Academic Editors: Yves Bergeron and Sylvie Gauthier

Received: 29 February 2016; Accepted: 9 April 2016; Published: 15 April 2016

\begin{abstract}
Fire is the most common disturbance in northern boreal forests, and large fires are often associated with highly variable burn severities across the burnt area. We studied the understory plant community response to a range of burn severities and pre-fire stand age four growing seasons after the 2011 Richardson Fire in xeric jack pine forests of northern Alberta, Canada. Burn severity had the greatest impact on post-fire plant communities, while pre-fire stand age did not have a significant impact. Total plant species richness and cover decreased with disturbance severity, such that the greatest richness was in low severity burns (average 28 species per 1- $\mathrm{m}^{2}$ quadrat) and plant cover was lowest in the high severity burns (average 16\%). However, the response of individual plant groups differed. Lichens and bryophytes were most common in low severity burns and were effectively eliminated from the regenerating plant community at higher burn severities. In contrast, graminoid cover and richness were positively related to burn severity, while forbs did not respond significantly to burn severity, but were impacted by changes in soil chemistry with increased cover at $\mathrm{pH}>4.9$. Our results indicate the importance of non-vascular plants to the overall plant community in this harsh environment and that the plant community is environmentally limited rather than recruitment or competition limited, as is often the case in more mesic forest types. If fire frequency and severity increase as predicted, we may see a shift in plant communities from stress-tolerant species, such as lichens and ericaceous shrubs, to more colonizing species, such as certain graminoids.
\end{abstract}

Keywords: Pinus banksiana; burn severity; composite burn index; revegetation; forest regeneration; lichen

\section{Introduction}

Large fires are expected to become more common in northern boreal forests in the future with a changing climate [1], and these fire events are often characterized by highly variable burn severity [2-4]. Many studies have examined tree regeneration after variable severity burns in the boreal forest $[5,6]$, but in terms of overall plant diversity, understory species are most important, especially in the tree species-poor, xeric jack pine (Pinus banksiana) forests of the northern boreal [7]. Understory plant communities also play critical roles in maintaining key ecosystem processes, such as nutrient cycling, habitat for wildlife and overstory succession [8,9].

The regeneration mechanism of understory plants differs from that of the jack pine canopy trees, i.e., an aerial seedbank of serotinous cones that releases seeds immediately after burning $[10,11]$. In contrast, after fire in the northern boreal forest, understory plants may resprout from roots or rhizomes $[7,12,13]$, germinate from seeds in the soil seed bank [14,15], germinate from seeds carried in from off-site [16] or encroach from surrounding areas [17]. The relative importance of these different regeneration mechanisms differs by species and will likely be impacted by disturbance severity, stand 
age and soil properties. Previous work on jack pine regeneration after the same fire as this current study showed that stand age and burn severity were the main drivers of tree regeneration [2], but it is not clear if these same drivers are controlling understory plant community re-establishment.

The regeneration of understory plants may be impacted by high burn severities by altering seed bed availability, with most species requiring exposed mineral soil to germinate. High burn severities can also change the composition of surviving vegetation from which resprouting is possible by reducing or eliminating stored seedbanks in the organic material where most seeds are found and by eliminating competition [18]. Stand age has a clear impact on species composition related to the successional stage of forest development with more shade-tolerant species being found in older forests and species that are more adapted to the specific soil and site conditions rather than to disturbance [19]. This influences the species present on site and capable of vegetative reproduction, but may not influence regeneration from seed. Soil properties may also impact understory plant regeneration after disturbance to a greater degree than tree regeneration, as understory plant species are more sensitive to changes in soil chemical and physical properties than are tree species growing on the same sites. However, how these factors interact with each other and with environmental conditions to influence plant community establishment in boreal jack pine forests in the years following fire is not clear.

Most studies on forest understory plant community response to disturbance focus on vascular plants [20-22], which are the dominant plant groups in most mesic boreal forests and are more responsive to disturbance than non-vascular species [8]. However, in harsh environments within the boreal forest, such as the xeric jack pine-dominated forests that are the focus of this study, non-vascular lichens and bryophytes are a more significant component [7]. This also holds true for other harsh environments, such as bogs at the other end of the moisture gradient within the boreal forest, where the understory community is also dominated by non-vascular plant species, such as Sphagnum mosses. Less is known about the regeneration ecology of these non-vascular species when compared to herbaceous and shrub vegetation, and the response of the non-vascular community to varying levels of disturbance severity is not well understood [23,24].

We studied understory plant communities in response to a range of natural burn severities and pre-fire stand ages in the xeric jack pine boreal forest of north-eastern Alberta, Canada. This forest area is not currently being developed for timber, but will likely be impacted, at least in part, in the future by expanding oil sands developments. Therefore, it is important to gain a better understanding of how the plant communities in this area respond to varying levels of disturbance severity and identify any potential risks to ecosystem sustainability in a post-disturbance landscape. The specific questions we asked are: (1) How do burn severity and pre-fire stand age impact understory plant community development post-fire in these xeric, pure jack pine boreal forests? (2) Do all plant groups respond in a similar manner to these drivers?

\section{Methods}

\subsection{Study Area and Fire Description}

We examined plant community development four growing seasons after the Richardson Fire, a 576,000-ha fire in north-eastern Alberta, Canada (Figure 1). This fire resulted from human ignition, burned from May until August 2011 and was the second largest documented fire in western Canadian history. During periods of extreme fire weather, there were spread rates of over $30 \mathrm{~km}$ per day with modelled head fire intensities in excess of $10,000 \mathrm{~kW} \cdot \mathrm{m}^{-1}$.

The dominant forest type in the region is jack pine growing on sandy dystric Brunisol soils on aeolian parent material with common understory vegetation consisting of Arctostaphylos uva-ursi, Vaccinium myrtilloides and Cladonia arbusculata subsp. mitis. The local site type is referred to as the xeric "a" eco-site in the Canadian Shield and Boreal Mixedwood Ecological Areas [25]. The southern and western portions of the Richardson Burn also contain stands of more mesic trembling aspen 
(Populus tremuloides) and white spruce (Picea glauca) forest types, but this work focused on the jack pine-dominated portion of the burn, which accounts for $65 \%$ of the total burned area. The climate in the area is continental with long, cold winters (average January temperature $-19^{\circ} \mathrm{C}$ ) and short, cool summers (average July temperature $17^{\circ} \mathrm{C}$ ) (based on Fort McMurray climate normal from Environment Canada). Median annual precipitation is $455 \mathrm{~mm}$, which is less than the average annual potential evaporation of $480 \mathrm{~mm}$ [26]. The xeric site type and moisture-limiting climate indicate that these forests are very challenging environments for many types of plants to grow, and this is supported by the low basal area (average $16.3 \mathrm{~m}^{2} \cdot \mathrm{ha}^{-1}$ ) and short canopy height (average $11.8 \mathrm{~m}$ ) for mature jack pine stands [2].

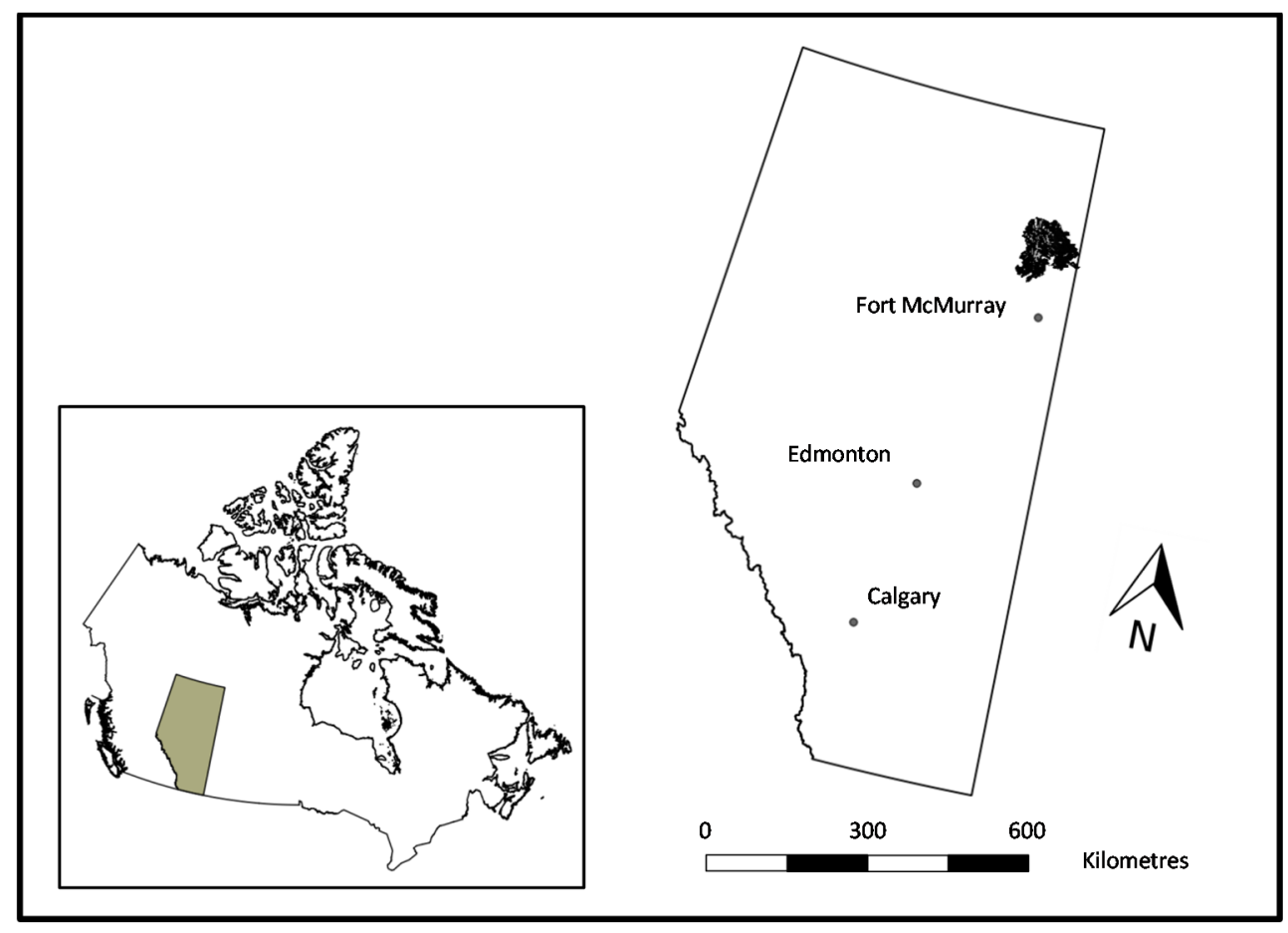

Figure 1. Location of the 2011 Richardson Fire in northeastern Alberta, Canada.

\subsection{Field Sampling}

The sampling design was based on a previous project [2], which examined jack pine regeneration after the Richardson Burn in stands of different pre-fire age and burn severity. For the current study, we used this matrix of three burn severities (low, moderate and high) and two pre-fire stand ages (young and old) and measured understory plant community composition in six or seven stands within each of the six categories for a total of 38 stands. Selected stands had pure jack pine overstories with the pre-fire stand age and burn severity determined in the year immediately following the fire as part of the pine regeneration study. Burn severity was determined using the Composite Burn Index (CBI), which incorporates measures of forest floor, understory and overstory burn severity [27], and was then categorized as low, moderate or high. High burn severity stands had complete overstory mortality and greater than $50 \%$ forest floor consumption; moderate burn severity stands had on average $75 \%$ overstory mortality and $25 \%-50 \%$ forest floor consumption; and low burn severity stands had $<25 \%$ overstory mortality and only light charring of the forest floor. Pre-fire stand ages were determined from cores taken at breast height of representative canopy trees. Stands were sampled according to pre-fire stand age, with stands less than 30 years old considered "young" and stands greater than 60 years old considered "old". Soil samples were taken from the upper $15 \mathrm{~cm}$ of mineral 
soil and were analyzed for texture, percent carbon, electrical conductivity (EC) and $\mathrm{pH}$, none of which were significantly different among burn severity or pre-fire stand age classes.

Plot centres were established at a random point within each selected stand, and then, four $1 \mathrm{~m} \times 1 \mathrm{~m}$ quadrats were located $10 \mathrm{~m}$ from the plot centre along cardinal bearings. This size of quadrat was used, as it is the standard in the region and will allow for comparison with other studies. At each quadrat, all vascular and non-vascular plants, including lichens, were identified to the species level, and cover was visually estimated to the nearest percent with cover values of $0.5 \%$ and + (present but at lower than $0.5 \%$ cover) also recorded. A complete stand level species list was also developed for the area enclosed by the four quadrats, an area of approximately $300 \mathrm{~m}^{2}$, by completing a walkaround survey. For quantitative analyses, the average cover at the stand level was used with + assigned a value of $0.05 \%$ and presence in the area enclosed by the quadrats, but not in the quadrats themselves, assigned a cover value of $0.005 \%$. Total species richness (the total number of understory species per stand) and average percent cover of vegetation (the average of the four quadrats) were determined for each stand. Richness and cover by species group, i.e., lichen, bryophyte, graminoid, forb, shrub, were also determined. Species nomenclature was standardized for vascular plants [28], bryophytes [29] and lichens [30].

\subsection{Statistical Analyses}

Non-metric multidimensional scaling (NMDS) ordinations were used to identify patterns of understory species composition with the Sorensen (Bray-Curtis) distance used as a measure of ecological dissimilarity in the NMDS ordinations conducted using PC-ORD [31]. To quantify the multi-variate differences between groups, we used the multi-response permutation procedure (MRPP) in PC-ORD with Bonferroni correction of post hoc pairwise comparisons conducted in R [32]. These ordinations were completed for all plant species together and then for the vascular plants and non-vascular plants (lichens and bryophytes) separately. Indicator species analysis [33], conducted in PC-ORD, was used to identify characteristic species for each burn severity class. This method combines the relative abundance of a species with its relative frequency of occurrence within each burn severity type, producing a maximum value $(100 \%)$ when all individuals of a species are found in a single burn severity type and when the species occurs in all samples within that type. Significance of each species as an indicator was tested for the burn severity type in which it reached its maximum value using a randomization procedure.

Two-way ANOVA followed by Tukey post hoc tests were used to compare species richness and cover among burn severity and pre-fire stand age groups. Regression analysis was used to determine the specific relationship between species groups' richness and cover and continuous site and environmental variables, including burn severity and soil $\mathrm{pH}$. Regression tree analysis was used to quantify distinct thresholds in the response variables. These analyses were conducted using Systat13 (Systat Software Inc., Chicago, IL, USA).

\section{Results}

There was a total of 95 plant (including lichen) species (Appendix A) found across all stands with the most numerous species group being lichens with 32 different species found followed by forbs with 31 species found. Stand-level species richness decreased with burn severity and pre-fire stand age (Figure 2a), such that the greatest richness was found in young stands with low burn severity, and the lowest richness was found in old stands with high burn severity. Vascular plant richness, when considered separately, showed no significant differences among burn severity $(p=0.885)$ or age classes $(p=0.537)$. Average stand level total plant cover ranged from $4 \%-63 \%$ and also decreased with burn severity, but was not affected by pre-fire stand age (Figure $2 b$ ).

The ordination including all vegetation (Figure 3 ) and supported by MRPP clearly shows differing plant communities among burn severity classes $(\mathrm{A}=0.072, p<0.001)$, but there were no significant differences among pre-fire age classes $(\mathrm{A}=0.010, p=0.083)$. Axis 1 is positively correlated with burn 
severity and graminoid cover, while lichen richness and cover were negatively correlated (Figure 3a). Axes 2 and 3 function mostly as a soil chemistry gradient with $\mathrm{pH}$ and EC positively related to forb and shrub richness (Figure $3 a, b)$.

Including only vascular vegetation in the ordination clearly separates the stand replacing moderate and high severity burns from the low severity burns and results in a main gradient defined by burn severity $(\mathrm{A}=0.068, p<0.001)$ and a secondary gradient associated with soil variables, but there was no difference among pre-fire stand age classes $(\mathrm{A}=-0.004, p=0.645)$ (Figure 4a). When only non-vascular species are included in the ordination, high severity burns are clearly separated with burn severity again being the primary factor along Axis $1(\mathrm{~A}=0.045, p=0.003)$, but there is no difference among pre-fire stand age classes $(\mathrm{A}=-0.003, p=0.302)$ (Figure $4 \mathrm{~b})$. In this ordination, the secondary gradient is negatively correlated with greater lichen richness and positively with forb cover.

a)

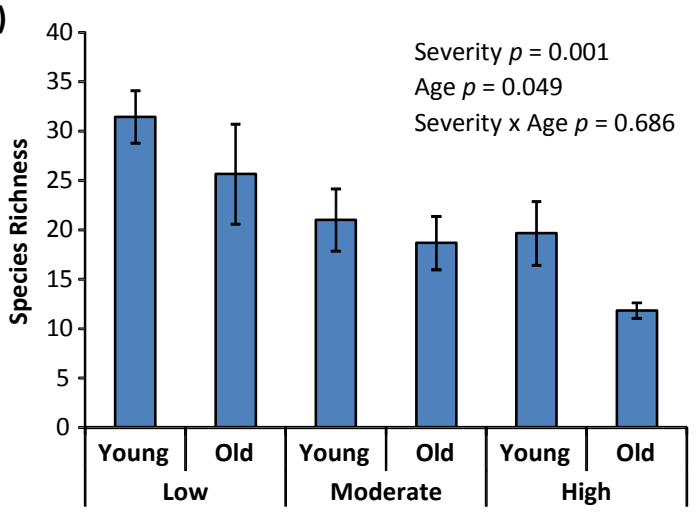

b)

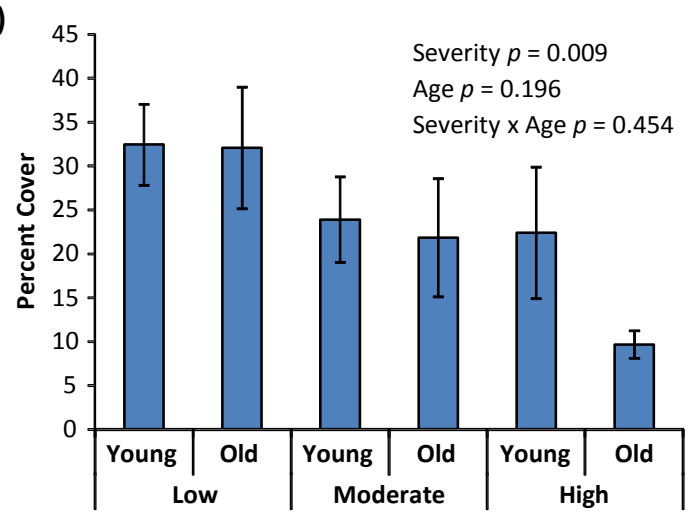

Figure 2. (a) Species richness (total number of plant species found in each stand) and (b) percent cover (total cover of all species averaged from four $1 \mathrm{~m} \times 1 \mathrm{~m}$ quadrats per stand), in relation to burn severity (as measured by the Composite Burn Index) and pre-fire stand age.

a)

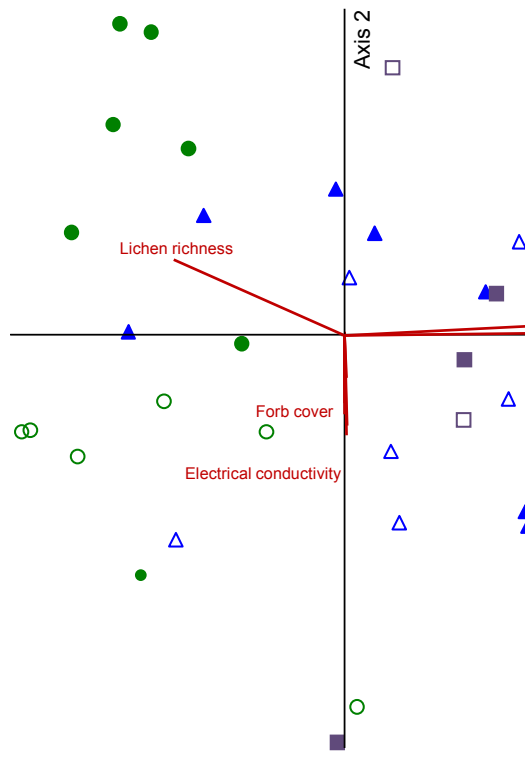

b)

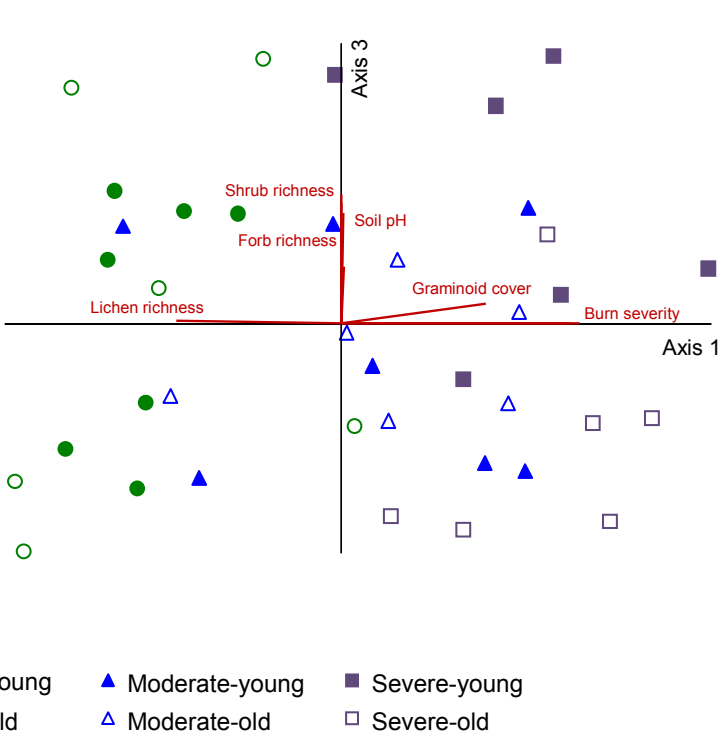

Figure 3. Non-metric multidimensional scaling ordination of all plant community data: (a) Axes 1 and 2; (b) Axes 1 and 3. The environmental overlays present the most significant relationships for each species group, burn severity and soil chemistry with $r>0.5$. 
a)

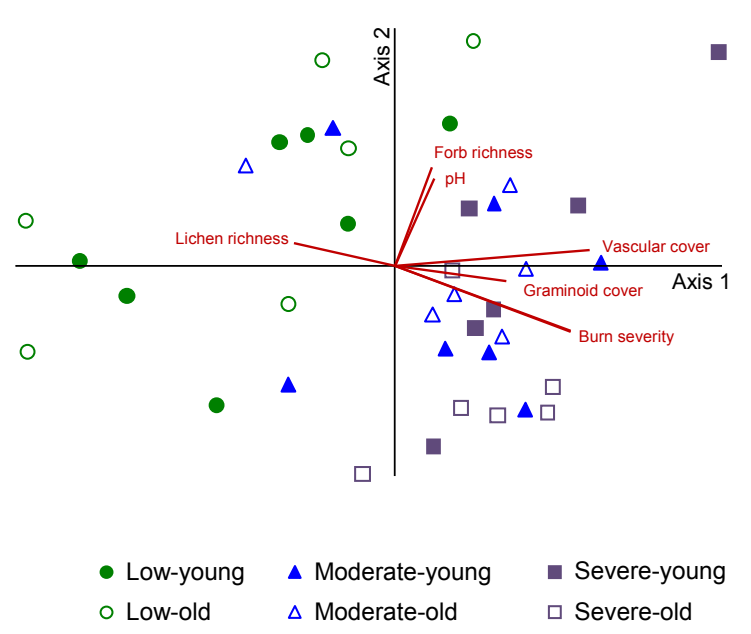

b)

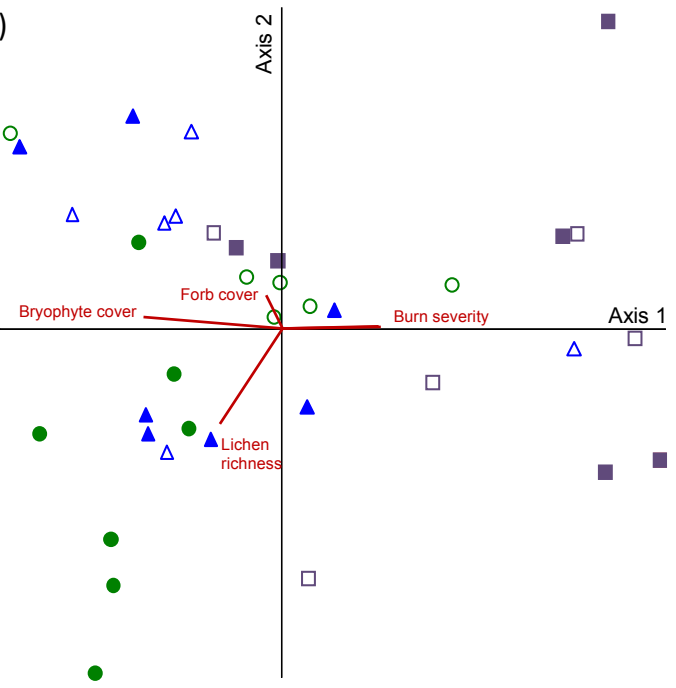

Figure 4. Non-metric multidimensional scaling ordination including only (a) vascular plants or (b) non-vascular plants. The environmental overlays present the most significant relationships for each species group, burn severity and soil chemistry with $r>0.5$.

Lichen species, mainly from the genus Cladonia with the most common species being Cladonia arbusculata subsp. mitis and Cladonia gracilis subsp. turbinata, which were found in 16 out of 38 stands each, accounted for $70 \%$ of total cover and $38 \%$ of the total species richness in low severity burns where they were most common. Lichen cover showed a negative relationship to burn severity with a significant threshold at CBI 1.9, with lichens being effectively eliminated from the plant community beyond this point (Figure 5a). Bryophyte cover showed a similar pattern to lichens with a negative relationship to burn severity, but with an elimination threshold at a higher burn severity of $2.5 \mathrm{CBI}$ (Figure 5b). The most common bryophytes were Ceratodon purpureus and Polytrichum piliferum, which were found in 37 and 30 of 38 stands, respectively. P. piliferum along with the two lichen species C. arbusculata subsp. mitis and C. gracilis subsp. turbinata were the strongest indicators of low severity burns (Table 1), but C. purpureus, a ubiquitous species associated with disturbance and open sandy soils, was not a significant indicator of burn severity (Table 1).

Graminoid cover, on the other hand, was quite low (average 2.1\% across all burn severities), but was positively related to burn severity (Figure 5c). Graminoid species richness was also positively correlated to burn severity $(r=0.468, p=0.003)$ with the rhizomatous, quickly colonizing Carex siccata indicative of moderate and high severity burns (Table 1).

Forb cover was low overall (average 1.2\%) and was not related to burn severity $(p=0.802)$ or pre-fire stand age $(p=0.409)$, but it was related to soil $\mathrm{pH}$ with significantly higher $(p<0.05)$ forb cover on soils with $\mathrm{pH}>4.9$ (average $4.1 \%$ ) compared to soils with $\mathrm{pH}<4.9$ (average $0.8 \%$ ). The most common forbs were Solidago simplex, Campanula rotundifolia and Apocynum androsaemifolia, which were found in 24, 20 and 15 of 38 plots, respectively, across the range of soil $\mathrm{pH}$. On the higher $\mathrm{pH}$ soils, however, Maianthemum canadense and Cornus canadensis became dominant, with the highest forb cover values found in any stands associated with these two species. Colonizing species with small windblown seeds, such as Chamerion angustifolium and Symphyotrichum laeve, were each only found in nine of 38 stands. Although not as ubiquitous, the annual forbs Erigeron canadensis and Leucophysalis grandiflora were both significant indicators of high severity burns (Table 1).

Shrub cover averaged $3.8 \%$ and was not related to burn severity $(p=0.520)$, pre-fire stand age $(p=0.189)$ nor measured soil properties $(\mathrm{pH}, p=0.272)$. The most common species were all low shrubs, mainly ericaceous, with Arctostaphylos uva-ursi, Hudsonia tomentosa and Vaccinium myrtilloides being found in 38, 24 and 22 of 38 stands, respectively, and there were no significant shrub indicators of burn severity. 


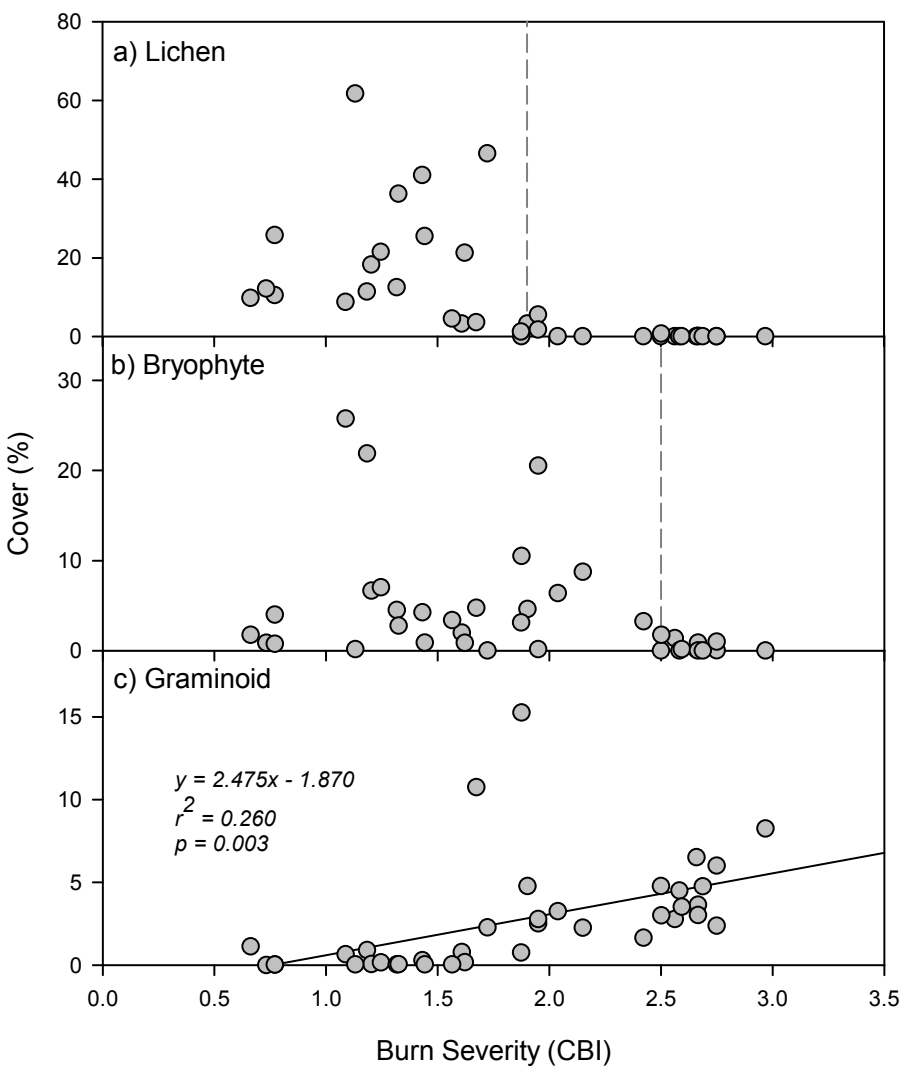

Figure 5. Relationships between the cover of plant groups and burn severity as measured by the Composite Burn Index (CBI) for (a) lichens, (b) bryophytes and (c) graminoids. The thresholds for lichen cover at $1.9 \mathrm{CBI}$ and bryophyte cover at $2.5 \mathrm{CBI}$ were determined from regression tree analysis at a significance level of $p<0.05$.

Table 1. Significant indicator species with an indicator value $>25$ for each burn severity class as determined by the method of Dufrêne and Legendre [33]. Each species was only tested for significance in the group for which it had its maximum indicator value.

\begin{tabular}{cccccc}
\hline Severity & Indicator Species & $\begin{array}{c}\text { Indicator } \\
\text { Value }\end{array}$ & $p$ & $\begin{array}{c}\text { Growth } \\
\text { Form }\end{array}$ & $\begin{array}{c}\text { Life } \\
\text { Strategy }\end{array}$ \\
\hline Low & Cladonia arbusculata subsp. mitis & 82.1 & 0.0002 & lichen & perennial \\
& Cladonia gracilis subsp. turbinata & 76 & 0.0008 & lichen & perennial \\
& Polytrichum piliferum & 75.4 & 0.0034 & moss & perennial \\
& Pyrola chlorantha & 64.7 & 0.001 & forb & perennial \\
& Cladonia pyxidata & 59.1 & 0.0002 & lichen & perennial \\
& Cladonia deformis & 54.3 & 0.0008 & lichen & perennial \\
& Trapeliopsis granulosa & 50.1 & 0.011 & lichen & perennial \\
& Cladonia sulphurina & 47.7 & 0.0012 & lichen & perennial \\
& Cladonia subulata & 45.7 & 0.003 & lichen & perennial \\
& Cetraria ericetorum & 44.7 & 0.0042 & lichen & perennial \\
& Cladonia uncialis & 43.6 & 0.0432 & lichen & perennial \\
& Cladonia botrytes & 41.7 & 0.0056 & lichen & perennial \\
& Parmeliopsis ambigua & 38.5 & 0.0074 & lichen & perennial \\
& Cladonia cristatella & 38 & 0.0124 & lichen & perennial \\
& Peltigera malacea & 37 & 0.0184 & lichen & perennial \\
& Cladonia cornuta & 36.6 & 0.0334 & lichen & perennial \\
& Dicranum polysetum & 35.3 & 0.0238 & moss & perennial \\
& Vulpicida pinastri & 30.8 & 0.0284 & lichen & perennial \\
& Cladonia borealis & 28 & 0.0498 & lichen & perennial \\
& Carex siccata & 29 & - & graminoid & perennial \\
Moderate & Carex siccata & 69.6 & 0.0252 & graminoid & perennial \\
High & Erigeron canadensis & 31.9 & 0.0338 & forb & annual \\
& Leucophysalis grandiflora & 25 & 0.0272 & forb & annual \\
\hline
\end{tabular}




\section{Discussion}

There are distinct plant communities developing four years after burns of differing severity, and three out of five main species groups (lichens, bryophytes and graminoids) responded significantly to burn severity. Low severity burns favour the persistence of lichens and bryophytes and have higher overall species richness than high severity burns. In contrast, the vegetation community after high severity burns is comprised mainly of annual forbs and colonizer-type graminoids seeding in from off site along with resprouting forbs and shrubs, resulting in lower overall species diversity and cover. Species richness did not increase with moderate levels of disturbance, as has been suggested by other studies [34,35], but instead, species richness declined with burn severity in our study. While peaks in species richness at intermediate levels of disturbance are actually the exception rather than the rule in published studies [36], the intermediate disturbance hypothesis and underlying mechanisms are fundamental concepts in community ecology, and it is important to understand under what situations these mechanisms function. In our study, in a climatically marginal forest area and on a xeric site type, the number of species capable of surviving there is much less than are available to a more mesic site type, indicating that the plant community developing here may be environmentally limited rather than recruitment or competition limited. Certainly, it is the trade-off between early successional species adapted for colonization (colonizers) versus later successional species better able to compete for resources (competitors) that is thought to be one of the primary mechanisms responsible for the peak in species richness at intermediate levels of disturbance [35,37]. While no peak in richness at moderate burn severity was observed in our study, differential species responses to disturbance were observed.

High severity burns, which result in a loss of more than $50 \%$ of the total forest floor, result in greatly reduced species richness, as much of the seedbank and resprouting organs are found in the forest floor $[12,15]$. The new forest plant community must therefore rely mainly on colonizing species from outside, of which there appear to be few other than select graminoids and forbs, capable of surviving in this harsh environment. It also appears that competition between plants is not a major component in determining community composition in this forest given the low overall vegetation cover $(16 \% \pm 4 \%$ (mean \pm SE) in high severity burns) and the corresponding high level of bare ground, again indicating that environmental and not internal controls (i.e., competition) are mainly responsible for controlling plant community development. In contrast, after the same fire event, mesic boreal mixedwood sites had much greater vegetation cover and species richness [22] indicative of higher competition levels among plants and suggesting that this xeric jack pine forest responds differently to fire than do nearby mesic forests.

Lichens and bryophytes were completely eliminated from the plant community at high burn severity, a response frequently evident in non-vascular plants following high severity burns [38]. Although generally considered to be dispersal limited [39], lichens are expected to begin initial recolonization one to three years following the fire, with pioneer lichen species, such as Cladonia coccifera (likely equivalent to our C. borealis) and C. gracilis [7]. Both of these pioneer species were found in our study, although they were confined to low and moderate severity burns and likely represent relict populations from pre-fire communities. Four years post-fire, lichens are only just beginning to recolonize the most severely-burnt sites, with Cladonia species present in seven of the twelve stands, but in early stages of regeneration (basal scales only). This is consistent with a generalized successional sequence found throughout lichen-dominated forests of the northern taiga and tundra regions [40]. The bryophytes Polytrichum piliferum and P. juniperinum were both detected in all age and burn severity classes, along with the ubiquitous Ceratodon purpureus. The presence of these species is typical of post-fire succession in northern boreal forests and indicates that these moss species are not dispersal limited, as is hypothesized for lichens. Increased bryophyte diversity in the low and moderate severity burns is also typical of later successional sequences and indicates persistence after low severity burns rather than recolonization. While this general successional sequence of non-vascular plants has been documented in black spruce (Picea mariana) [41], lodgepole pine (Pinus contorta var. latifolia) [42] and jack pine/lichen forests [7], xeric jack pine lichen forests in northern Alberta may follow an alternate 
successional trajectory leading to a final park-like pine/lichen stage, instead of the more closed canopy pine/feathermoss stage [7].

Unlike bryophytes and lichens, graminoid cover increased with burn severity. Most of these species are thought to seed in from outside areas, but they may have been a component of the seedbank. Other studies from more southern, climatically-favourable jack pine forests have described the rapid expansion of graminoids, particularly Carex, after disturbance with possible negative implications for tree regeneration [43], but the low cover values for graminoids in our study (average $4.4 \%$ in high severity) indicate that is not a concern in this forest area. The lack of graminoids in low severity burns with little disturbance to the forest floor also indicates that these species are transient members of the plant community and are likely not a substantial part of the mature forest understory.

Forb cover and richness were not related to burn severity, but were related to soil chemistry with increased cover above $\mathrm{pH}$ 4.9. This is comparable to more forb-rich aspen stands of the region, which were found to have $\mathrm{pH}( \pm \mathrm{SE})$ values of $5.28 \pm 0.33$ and $4.77 \pm 0.19$ for mature and post-fire stands, respectively [22]. The lack of response to burn severity may reflect the vegetative regeneration strategy of many common perennial forb species, including the species most abundant on high $\mathrm{pH}$ soils, Maianthemum canadense and Cornus canadensis $[44,45]$. Even on sites with very low competition levels and correspondingly high suitable seedbeds in the form of exposed mineral soil, forb richness did not increase, suggesting that colonizing forb species with widely-dispersed seed rain, such as Chamerion angustifolium and Symphyotrichum laeve [46,47], were not able to thrive in this harsh environment. Instead, the sites with the most abundant forb cover relied on resprouting of existing forbs.

Shrub cover and richness were not related to burn severity, pre-fire stand age or any measured environmental variable. Most shrubs can regenerate vegetatively, and this appears to be the case here with similar shrub species found across the range of site types and burn severities. The low shrub cover (average 3.8\% across all sites) may therefore be more indicative of the slow growth rates of the dominant ericaceous shrubs, rather than a limitation in recruitment to the site given that Arctostaphylos uva-ursi was found in every sampled stand.

\section{Conclusions}

In conclusion, we demonstrate the relatively large range of potential plant communities developing following a large, spring fire in xeric, boreal jack pine forests. Although there are indications that soil chemical factors play a secondary role in structuring the forb community, four years post-fire, the variation in plant communities is primarily due to burn severity and is evident in both the vascular and non-vascular components of the flora. If fire frequency and severity continue to increase as predicted [1], these results indicate that we may see a shift in plant communities from stress-tolerant, slower growing species, such as lichens and ericaceous shrubs, to more colonizing species, such as select graminoids and forbs, which appear to be able to tolerate the harsh environmental conditions of this forest. The implications of this potential shift in understory plant communities on wildlife habitat, particularly for the woodland caribou, which rely on lichen for much of their diet, is not known. As this study was based on only a single, albeit massive, fire event, caution is needed in extrapolating these results to other areas. The clear message from this study, however, is that the potential range of post-disturbance plant communities is dependent on burn severity at the site level.

Acknowledgments: Thanks to Edith Li for field assistance and Brent Frey and Andre Arsenault for reviewing an earlier draft of the manuscript. Funding for this project was provided by Natural Resources Canada, Canadian Forest Service.

Author Contributions: Bradley D. Pinno and Ruth C. Errington both contributed to all aspects of the work, including designing the experiment, analyzing the data and writing the paper.

Conflicts of Interest: The authors declare no conflict of interest. 


\section{Appendix A}

Table A1. Complete species list with the number of stands the species was found in grouped according to burn severity and pre-fire age class.

\begin{tabular}{|c|c|c|c|c|c|c|c|c|}
\hline \multirow{2}{*}{$\begin{array}{c}\text { Burn Severity } \\
\text { Age Class }\end{array}$} & & & \multicolumn{2}{|c|}{ Low } & \multicolumn{2}{|c|}{ Moderate } & \multicolumn{2}{|c|}{ High } \\
\hline & & & Old & Young & Old & Young & Old & Young \\
\hline Number of plots per stand type & & & $\mathrm{N}=6$ & $\mathrm{~N}=7$ & $\mathrm{~N}=6$ & $\mathrm{~N}=7$ & $\mathrm{~N}=6$ & $\mathrm{~N}=6$ \\
\hline Species & Layer & Life Strategy & & & & & & \\
\hline Achillea millefolium Linnaeus & herb & perennial & 0 & 2 & 0 & 0 & 0 & 0 \\
\hline Agrostis scabra Willdenow & herb & perennial & 5 & 6 & 5 & 7 & 6 & 5 \\
\hline Alnus viridis (Chaix) de Candolle subsp. crispa (Aiton) Turrill & shrub & perennial & 0 & 0 & 0 & 1 & 0 & 1 \\
\hline Amelanchier alnifolia (Nuttall) Nuttall ex M. Roemer & shrub & perennial & 1 & 1 & 1 & 0 & 0 & 2 \\
\hline Anemone multifida Poiret & herb & perennial & 2 & 1 & 1 & 0 & 0 & 2 \\
\hline Apocynum androsaemifolium Linnaeus & herb & perennial & 3 & 3 & 2 & 3 & 1 & 4 \\
\hline Aralia nudicaulis Linnaeus & herb & perennial & 0 & 0 & 0 & 0 & 0 & 1 \\
\hline Arctostaphylos uva-ursi (Linnaeus) Sprengel & shrub & perennial & 6 & 7 & 6 & 7 & 6 & 6 \\
\hline Bryoria simplicior (Vainio) Brodo \& D. Hawksw. & lichen & perennial & 0 & 1 & 0 & 0 & 0 & 0 \\
\hline Calamagrostis stricta subsp. inexpansa (A. Gray) Greene & herb & perennial & 1 & 1 & 1 & 0 & 0 & 2 \\
\hline Campanula rotundifolia Linnaeus & herb & perennial & 3 & 5 & 3 & 3 & 1 & 4 \\
\hline Capnoides sempervirens (Linnaeus) Borkhaussen & herb & biennial & 0 & 0 & 0 & 0 & 1 & 0 \\
\hline Carex foenea Willdenow & herb & perennial & 0 & 1 & 2 & 4 & 2 & 4 \\
\hline Carex praticola Rydberg & herb & perennial & 0 & 0 & 1 & 0 & 0 & 0 \\
\hline Carex c.f. richardsonii $\mathrm{R}$. Brown & herb & perennial & 1 & 0 & 1 & 0 & 0 & 1 \\
\hline Carex siccata Dewey & herb & perennial & 4 & 5 & 6 & 7 & 6 & 6 \\
\hline Carex tonsa (Fernald) E.P. Bicknell & herb & perennial & 5 & 7 & 5 & 7 & 5 & 6 \\
\hline Carex umbellata Schkuhr ex Willdenow & herb & perennial & 0 & 0 & 1 & 0 & 1 & 0 \\
\hline Ceratodon purpureus (Hedwig) Bridel & bryophyte & perennial & 6 & 7 & 6 & 7 & 6 & 5 \\
\hline Cetraria ericetorum Opiz & lichen & perennial & 2 & 5 & 0 & 2 & 0 & 0 \\
\hline Chamerion angustifolium (Linnaeus) Holub subsp. angustifolium & herb & perennial & 0 & 1 & 3 & 1 & 1 & 3 \\
\hline Cladonia amaurocraea (Flörke) Schaerer & lichen & perennial & 0 & 1 & 0 & 0 & 0 & 0 \\
\hline Cladonia borealis $\mathrm{S}$. Stenroos & lichen & perennial & 0 & 5 & 0 & 2 & 0 & 0 \\
\hline Cladonia botrytes (K.G. Hagen) Willd. & lichen & perennial & 1 & 5 & 0 & 2 & 0 & 0 \\
\hline Cladonia cariosa (Ach.) Sprengel & lichen & perennial & 0 & 1 & 0 & 0 & 0 & 0 \\
\hline Cladonia cornuta (L.) Hoffm. & lichen & perennial & 0 & 5 & 0 & 3 & 0 & 0 \\
\hline Cladonia crispata (Ach.) Flotow & lichen & perennial & 0 & 4 & 1 & 2 & 0 & 0 \\
\hline
\end{tabular}


Table A1. Cont.

\begin{tabular}{|c|c|c|c|c|c|c|c|c|}
\hline \multirow{2}{*}{$\begin{array}{c}\text { Burn Severity } \\
\text { Cladonia cristatella Tuck. }\end{array}$} & \multirow[b]{2}{*}{ lichen } & \multirow[b]{2}{*}{ perennial } & \multicolumn{2}{|c|}{ Low } & \multicolumn{2}{|c|}{ Moderate } & \multicolumn{2}{|c|}{ High } \\
\hline & & & 1 & 5 & 0 & 2 & 0 & 0 \\
\hline Cladonia deformis (L.) Hoffm. & lichen & perennial & 2 & 7 & 0 & 3 & 0 & 0 \\
\hline Cladonia c.f. fimbriata (L.) Fr. & lichen & perennial & 2 & 1 & 0 & 0 & 0 & 0 \\
\hline Cladonia gracilis (L.) Willd. subsp. turbinata (Ach.) Ahti & lichen & perennial & 3 & 7 & 2 & 3 & 0 & 0 \\
\hline Cladonia macilenta Hoffm. & lichen & perennial & 1 & 0 & 0 & 0 & 0 & 0 \\
\hline Cladonia macrophylla (Schaerer) Stenh. & lichen & perennial & 0 & 0 & 0 & 1 & 0 & 0 \\
\hline Cladonia arbusculata (Wallr.) Flotow subsp. mitis (Sandst.) Ruoss & lichen & perennial & 4 & 7 & 1 & 3 & 0 & 0 \\
\hline Cladonia multiformis G. Merr. & lichen & perennial & 1 & 1 & 0 & 0 & 0 & 0 \\
\hline Cladonia pyxidata (L.) Hoffm. & lichen & perennial & 2 & 6 & 0 & 1 & 0 & 0 \\
\hline Cladonia rangiferina (L.) F.H. Wigg. & lichen & perennial & 1 & 0 & 0 & 0 & 0 & 0 \\
\hline Cladonia sp. P. Browne & lichen & perennial & 6 & 6 & 5 & 5 & 4 & 3 \\
\hline Cladonia stygia (Fr.) Ruoss & lichen & perennial & 1 & 0 & 0 & 0 & 0 & 0 \\
\hline Cladonia subulata (L.) F.H. Wigg. & lichen & perennial & 1 & 5 & 0 & 1 & 0 & 0 \\
\hline Cladonia sulphurina (Michaux) Fr. & lichen & perennial & 2 & 5 & 0 & 2 & 0 & 0 \\
\hline Cladonia uncialis (L.) Weber ex F.H. Wigg. & lichen & perennial & 4 & 5 & 1 & 3 & 0 & 0 \\
\hline Cladonia verticillata (Hoffm) Schaerer & lichen & perennial & 0 & 4 & 0 & 2 & 0 & 0 \\
\hline Collomia linearis Nuttall & herb & annual & 2 & 0 & 0 & 0 & 0 & 0 \\
\hline Comandra umbellata (Linnaeus) Nuttall & herb & perennial & 1 & 0 & 1 & 0 & 0 & 0 \\
\hline Cornus canadensis Linnaeus & herb & perennial & 1 & 0 & 0 & 0 & 0 & 1 \\
\hline Crepis tectorum Linnaeus & herb & annual & 0 & 0 & 3 & 0 & 0 & 1 \\
\hline $\begin{array}{l}\text { Dichanthelium acuminatum (Swartz) Gould \& C.A. Clarke subsp. fasciculatum } \\
\text { (Torrey) Freckmann \& Lelong }\end{array}$ & herb & perennial & 0 & 0 & 0 & 1 & 1 & 0 \\
\hline Dicranum polysetum Swatrtz & bryophyte & perennial & 4 & 1 & 1 & 0 & 0 & 0 \\
\hline Diphasiastrum complanatum (Linnaeus) Holub & herb & perennial & 1 & 1 & 0 & 0 & 0 & 1 \\
\hline Erigeron canadensis Linnaeus & herb & annual & 0 & 0 & 3 & 0 & 2 & 3 \\
\hline Evernia mesomorpha Nyl. & lichen & perennial & 0 & 1 & 0 & 0 & 0 & 0 \\
\hline Festuca saximontana Rydberg & herb & perennial & 1 & 0 & 0 & 0 & 0 & 0 \\
\hline Flavocetraria nivalis (L.) Kärnefelt \& A. Thell & lichen & perennial & 0 & 2 & 0 & 0 & 0 & 0 \\
\hline Fragaria virginiana Miller & herb & perennial & 2 & 1 & 1 & 0 & 0 & 1 \\
\hline Galium boreale Linnaeus & herb & perennial & 2 & 2 & 1 & 0 & 0 & 1 \\
\hline Geocaulon lividum (Richardson) Fernald & herb & perennial & 0 & 0 & 0 & 0 & 0 & 1 \\
\hline Geranium bicknellii Britton & herb & annual or biennial & 0 & 0 & 1 & 1 & 0 & 2 \\
\hline Hieracium umbellatum Linnaeus & herb & perennial & 2 & 1 & 0 & 0 & 1 & 1 \\
\hline Hudsonia tomentosa Nuttall & herb & perennial & 2 & 3 & 4 & 6 & 5 & 4 \\
\hline Hylocomium splendens (Hedwig) Shimper in P. Bruch and W.P. Shimper & bryophyte & perennial & 1 & 0 & 0 & 0 & 0 & 0 \\
\hline
\end{tabular}


Table A1. Cont.

\begin{tabular}{|c|c|c|c|c|c|c|c|c|}
\hline \multirow{2}{*}{\begin{tabular}{|c|} 
Burn Severity \\
Leucophysalis grandiflora (Hooker) Rydberg
\end{tabular}} & \multirow[b]{2}{*}{ herb } & \multirow[b]{2}{*}{ annual } & \multicolumn{2}{|c|}{ Low } & \multicolumn{2}{|c|}{ Moderate } & \multicolumn{2}{|c|}{ High } \\
\hline & & & 0 & 0 & 0 & 1 & 0 & 3 \\
\hline Leymus innovatus (Beal) Pilger subsp. innovatus & herb & perennial & 0 & 0 & 0 & 0 & 0 & 1 \\
\hline Linnaea borealis Linnaeus & herb & perennial & 3 & 1 & 1 & 0 & 0 & 1 \\
\hline Maianthemum canadense Desfontaines & herb & perennial & 3 & 3 & 2 & 2 & 1 & 3 \\
\hline Melampyrum lineare Desrousseaux & herb & annual & 1 & 0 & 0 & 0 & 0 & 0 \\
\hline Oryzopsis asperifolia Michaux & herb & perennial & 1 & 2 & 1 & 0 & 0 & 1 \\
\hline Packera paupercula (Michaux) Á. Löve \& D. Löve & herb & perennial & 1 & 1 & 0 & 0 & 0 & 1 \\
\hline Parmeliopsis ambigua (Wulfen) Nyl. & lichen & perennial & 2 & 3 & 0 & 0 & 0 & 0 \\
\hline Peltigera malacea (Ach.) Funck & lichen & perennial & 2 & 3 & 0 & 1 & 0 & 0 \\
\hline Peltigera rufescens (Weiss) Humb. & lichen & perennial & 0 & 2 & 0 & 0 & 0 & 0 \\
\hline Pinus banksiana Lambert & tree & perennial & 4 & 7 & 6 & 7 & 6 & 6 \\
\hline Piptatheropsis pungens (Torrey ex Sprengel) Romaschenko, P.M. Peterson \& Soreng & herb & perennial & 4 & 4 & 2 & 5 & 4 & 5 \\
\hline Pleurozium schreberi (Wildenow ex Bridel) Mitten & bryophyte & perennial & 2 & 1 & 1 & 0 & 0 & 0 \\
\hline Polytrichum juniperinum Hedwig & bryophyte & perennial & 5 & 6 & 5 & 3 & 2 & 2 \\
\hline Polytrichum piliferum Hedwig & bryophyte & perennial & 6 & 7 & 5 & 6 & 2 & 2 \\
\hline Populus tremuloides Michaux & tree & perennial & 1 & 1 & 0 & 2 & 0 & 1 \\
\hline Prunus pensylvanica Linnaeus $\mathrm{f}$. & tree, shrub & perennial & 3 & 1 & 2 & 2 & 1 & 3 \\
\hline Ptilidium ciliare (L.) Hampe & bryophyte & perennial & 2 & 1 & 1 & 0 & 0 & 0 \\
\hline Ptilium crista-castrensis (Hedwig) De Notaris & bryophyte & perennial & 1 & 0 & 0 & 0 & 0 & 0 \\
\hline Pyrola chlorantha Swartz & herb & perennial & 4 & 5 & 1 & 2 & 0 & 1 \\
\hline Rosa acicularis Lindley & shrub & perennial & 1 & 1 & 1 & 0 & 0 & 1 \\
\hline Salix bebbiana Sargent & shrub & perennial & 0 & 2 & 0 & 0 & 0 & 0 \\
\hline Selaginella densa Rydb. & herb & perennial & 0 & 0 & 0 & 0 & 1 & 0 \\
\hline Sibbaldia tridentata (Aiton) Paule \& Soják & herb & perennial & 1 & 2 & 0 & 0 & 0 & 2 \\
\hline Solidago simplex Kunth var. simplex & herb & perennial & 3 & 4 & 5 & 4 & 4 & 3 \\
\hline Stereocaulon alpinum Laurer ex Funck & lichen & perennial & 0 & 1 & 0 & 0 & 0 & 0 \\
\hline Symphyotrichum ciliolatum (Lindley) Á. Löve \& D. Löve & herb & perennial & 0 & 1 & 0 & 1 & 0 & 0 \\
\hline Symphyotrichum laeve (Linnaeus) Á. Löve \& D. Löve var. laeve & herb & perennial & 3 & 1 & 2 & 0 & 0 & 3 \\
\hline Trapeliopsis granulosa (Hoffm.) Lumbsch & lichen & perennial & 2 & 5 & 0 & 3 & 0 & 0 \\
\hline unknown seedling & & $\# \mathrm{~N} / \mathrm{A}$ & 0 & 1 & 1 & 0 & 0 & 0 \\
\hline Vaccinium myrtilloides Michaux & shrub & perennial & 4 & 4 & 4 & 4 & 1 & 4 \\
\hline Vaccinium vitis-idaea Linnaeus & shrub & perennial & 3 & 1 & 2 & 1 & 0 & 2 \\
\hline Viola adunca Smith & herb & perennial & 1 & 1 & 1 & 0 & 0 & 2 \\
\hline Vulpicida pinastri (Scop.) J.-E. Mattsson \& M.J. Lai & lichen & perennial & 1 & 3 & 0 & 0 & 0 & 0 \\
\hline
\end{tabular}




\section{References}

1. deGroot, W.J.; Flannigan, M.D.; Cantin, A.S. Climate change impacts on future boreal fire regimes. For. Ecol. Manag. 2012, 294, 35-44.

2. Pinno, B.D.; Errington, R.C.; Thompson, D.K. Young jack pine and high severity fire combine to create potentially expansive areas of understocked forest. For. Ecol. Manag. 2013, 310, 517-522. [CrossRef]

3. Hollingsworth, T.N.; Johnstone, J.F.; Bernhardt, E.L.; Chapin, F.S., III. Fire severity filters regeneration traits to shape community assembly in Alaska's boreal forest. PLoS ONE 2013, 8, e56033. [CrossRef] [PubMed]

4. Lentile, L.B.; Smith, F.W.; Shepperd, W.D. Patch structure, fire-scar formation, and tree regeneration in a large mixed-severity fire in the South Dakota Black Hills, USA. Can. J. For. Res. 2005, 35, 2875-2885. [CrossRef]

5. Johnstone, J.F.; Chapin, F.S., III. Effects of soil burn severity on post-fire tree recruitment in boreal forest. Ecosystems 2006, 9, 14-31. [CrossRef]

6. Arsenault, D. Impact of fire behaviour on postfire forest development in a homogeneous boreal landscape. Can. J. For. Res. 2001, 31, 1367-1374.

7. Carroll, S.B.; Bliss, L.C. Jack pine-lichen woodland on sandy soils in northern Saskatchewan and northeastern Alberta. Can. J. Bot. 1982, 60, 2270-2282. [CrossRef]

8. Hart, S.A.; Chen, H.Y.Y. Vegetation dynamics of North American boreal forests. Crit. Rev. Plant Sci. 2006, 25, 381-397. [CrossRef]

9. Venier, L.A.; Pearce, J.L. Boreal forest landbirds in relation to forest composition, structure, and landscape: implications for forest management. Can. J. For. Res. 2007, 37, 1214-1226. [CrossRef]

10. Cayford, J.H.; McRae, D.J. The ecological role of fire in jack pine forests. In The Role of Fire in Northern Circumpolar Ecosystems; Wein, R.W., MacLean, D.A., Eds.; John Wiley \& Sons: Hoboken, NJ, USA, 1983; pp. 183-199.

11. Greene, D.F.; Johnson, E.A. Modelling recruitment of Populus tremuloides, Pinus banksiana, and Picea mariana following fire in the mixedwood boreal forest. Can. J. For. Res. 1999, 29, 462-473.

12. Archibold, O.W. Buried viable propagules as a factor in postfire regeneration in northern Saskatachewan. Can. J. Bot. 1979, 57, 54-58. [CrossRef]

13. Whittle, C.A.; Duchesne, L.C.; Needham, T. Soil seed bank of a jack pine (Pinus banksiana) ecosystem. Int. J. Wildland Fire. 1998, 8, 67-71. [CrossRef]

14. Morgan, P.; Neuenschwander, L.F. Seed-bank contributions to regeneration of shrub species after clear-cutting and burning. Can. J. Bot. 1988, 66, 169-172. [CrossRef]

15. Moore, J.M.; Wein, R.W. Viable seed populations by soil depth and potential site recolonization after disturbance. Can. J. Bot. 1977, 55, 2408-2412. [CrossRef]

16. Qi, M.; Scarratt, J.B. Effects of harvesting method on seed bank dynamics in a boreal mixedwood forest in northwestern Ontario. Can. J. Bot. 1998, 76, 872-883. [CrossRef]

17. Hautala, H.; Tolvanen, A.; Nuortila, C. Regeneration strategies of dominant boreal forest dwarf shrubs in response to selective removal of understorey layers. J. Veg. Sci. 2001, 12, 503-510. [CrossRef]

18. Roberts, M.R. Response of the herbaceous layer to natural disturbance in North American forests. Can. J. Bot. 2004, 82, 1273-1283. [CrossRef]

19. Hunt, S.L.; Gordon, A.M.; Morris, D.M.; Marek, G.T. Understory vegetation in northern Ontario jack pine and black spruce plantations: 20-year successional changes. Can. J. For. Res. 2003, 33, 1791-1803. [CrossRef]

20. Strong, W.L. Secondary vegetation and floristic succession within a boreal aspen (Populus tremuloides Michx.) clearcut. Can. J. Bot. 2004, 82, 1576-1585. [CrossRef]

21. Macdonald, S.E.; Fenniak, T.E. Understory plant communities of boreal mixedwood forests in western Canada: Natural patterns and responses to variable-retention harvesting. For. Ecol. Manag. 2007, 242, $34-48$. [CrossRef]

22. Errington, R.C.; Pinno, B.D. Early successional plant community dynamics on a reclaimed oil sands mine in comparison with natural boreal forest communities. Ecoscience 2016, in press.

23. Frego, K.A. Regeneration of four boreal bryophytes: colonization of experimental gaps by naturally occurring propagules. Can. J. Bot. 1996, 74, 1937-1942. [CrossRef]

24. Haeussler, S.; Bergeron, Y. Range of variability in boreal aspen plant communities after wildfire and clear-cutting. Can. J. For. Res. 2004, 34, 274-288. [CrossRef] 
25. Beckingham, J.D.; Archibald, J.H. Field Guide to Ecosites of Northern Alberta; Canadian Forest Service, Northwest Region, Northern Forestry Centre: Edmonton, AB, Canada, 1996.

26. Ozoray, G.; Hackbarth, D.; Lytviak, A.T. Earth Sciences Report 78-6. In Hydrogeology of the Bitumount-Namur Lake Area, Alberta; Alberta Research Council: Edmonton, AB, Canada, 1980.

27. Key, C.H.; Benson, N.C. Landscape assessment: Ground measure of severity, the composite burn index: And remote sensing of severity, the Normalized Burn Ratio. In FIREMON: Fire Effects Monitoring and Inventory System; Lutes, RMRS-GTR-164; Lutes, D.C., Keane, R.E., Caratti, J.F., Key, C.H., Benson, N.C., Sutherland, S., Gangi, L.J., Eds.; USDA Forest Service, Rocky Mountain Research Station: Ogden, UT, USA, 2006; pp. 1-51.

28. Brouillet, L.; Coursol, F.; Meades, S.J.; Favreau, M.; Anions, M.; Bélisle, P.; Desmet, P. VASCAN, the Database of Vascular Plants of Canada. Available online: http://data.canadensys.net/vascan/ (accessed on 4 December 2015).

29. Flora of North America Editorial Committee. Flora of North America North of Mexico; Oxford University Press: New York, NY, USA; Oxford, UK, 1993.

30. Esslinger, T.L. A Cumulative Checklist for the Lichen Forming, Lichenicolous and Allied Fungi of the Continental United States and Canada (Version 20); North Dakota State University: Fargo, ND, USA, 2015.

31. McCune, B.; Mefford, M.J. PC-ORD. Multivariate Analysis of Ecological Data; Version 6 MjM Software: Gleneden Beach, OR, USA, 2011.

32. R Core Team. R: A Language and Environment for Statistical Computing; R Foundation for Statistical Computing: Vienna, Austria, 2013.

33. Dufrêne, M.; Legendre, P. Species assemblages and indicator species: The need for a flexible asymmetrical approach. Ecol. Monogr. 1997, 67, 345-366. [CrossRef]

34. Mayor, S.J.; Cahill, J.F., Jr.; He, F.; Sólymos, P.; Boutin, S. Regional boreal biodiversity peaks at intermediate human disturbance. Nature Comm. 2012, 3, 1142. [CrossRef] [PubMed]

35. Grime, J.P. Competitive exclusion in herbaceous communities. Nature 1973, 242, 344-347.

36. Mackey, R.L.; Currie, D.J. The diversity-disturbance relationship: Is it generally strong and peaked? Ecology 2001, 82, 3479-3492.

37. Shea, K.; Roxburgh, S.H.; Rauschert, E.S. Moving from pattern to process: coexistence mechanisms under intermediate disturbance regimes. Ecol. Letters 2004, 7, 491-508. [CrossRef]

38. Webb, E.T. Survival, persistence, and regeneration of the reindeer lichens, Cladina stellaris, C. rangiferina, and C. mitis following clearcut logging and forest fire in northwestern Ontario. Rangifer 1998, 10, 41-47. [CrossRef]

39. Zouaoui, S.; Boudreault, C.; Drapeau, P.; Bergeron, Y. Influence of time since fire and micro-habitat availability on terricolous lichen communities in black spruce (Picea mariana) boreal forests. Forests 2014, 5, 2793-2809. [CrossRef]

40. Ahti, T.; Oksanen, J. Epigeic lichen communities of taiga and tundra regions. Vegetatio 1990, 86, 39-70. [CrossRef]

41. Maikawa, E.; Kershaw, K.A. Studies on lichen-dominated systems. XIX. The postfire recovery sequence of black spruce-lichen woodland in the Abitau Lake Region, NWT. Can. J. Bot. 1976, 54, 2679-2687. [CrossRef]

42. Coxson, D.S.; Marsh, J. Lichen chronosequences (postfire and postharvest) in lodgepole pine (Pinus contorta) forests of northern interior British Columbia. Can. J. Bot. 2001, 79, 1449-1464.

43. Abrams, M.D.; Dickmann, D.I. Early revegetation of clear-cut and burned jack pine sites in northern lower Michigan. Can. J. Bot. 1982, 60, 946-954. [CrossRef]

44. Pavek, D.S. Maianthemum canadense. In Fire Effects Information System; USDA Forest Service, Rocky Mountain Research Station, Fire Sciences Laboratory: Fort Collins, CO, USA, 1993.

45. Gucker, C.L. Cornus canadensis. In Fire Effects Information System; USDA Forest Service, Rocky Mountain Research Station, Fire Sciences Laboratory: Fort Collins, CO, USA, 2012.

46. Pavek, D.S. Chamerion angustifolium. In Fire Effects Information System; USDA Forest Service, Rocky Mountain Research Station, Fire Sciences Laboratory: Fort Collins, CO, USA, 1992.

47. Sullivan, J. Symphyotrichum leave. In Fire Effects Information System; USDA Forest Service, Rocky Mountain Research Station, Fire Sciences Laboratory: Fort Collins, CO, USA, 1992.

(C) 2016 by the authors; licensee MDPI, Basel, Switzerland. This article is an open access article distributed under the terms and conditions of the Creative Commons Attribution (CC-BY) license (http://creativecommons.org/licenses/by/4.0/). 